\title{
Epidemiology of pseudodactylogyrosis in an intensive eel-culture system
}

\author{
Kurt Buchmann \\ Department of Hygiene and Microbiology, Royal Veterinary and Agricultural University, Bülowsvej 13, DK-1870 \\ Frederiksberg C, Denmark
}

\begin{abstract}
Studies were performed on variations of prevalence and abundance in postlarvae and adults of the monogeneans Pseudodactylogyrus anguillae and $P$. bini from European eels in an intensive culture system. It appeared that a surge of settling parasite larvae always occurred after formaldehyde treatment of fish tanks, or after removal of bio-film from fish tank walls. Formaldehyde did not increase the susceptibility of eels to infection. The absence of postlarvae for certain periods was not caused by resistance of eels, which could be affected by dexamethasone-treatment. Settling of oncomiracidia was negatively correlated to activity of freeliving organisms in the biofilm on the fish tank wall. Laboratory tests showed that the biofilm-organism Stenostomum sp. (Turbellaria) ingested Pseudodactylogyrus eggs. It is suggested that predatory activity of biofilm organisms influences the infection level, although other factors may be of importance.
\end{abstract}

\section{INTRODUCTION}

Commercial eel farming has suffered seriously from infections by monogenean gill parasites Pseudodactylogyrus anguillae and P. bini (Ogawa \& Egusa 1976, Imada \& Muroga 1977, Egusa 1979, Chan \& Wu 1984, Chung et al. 1984, Buchmann et al. 1987). Factors influencing the parasites' life cycle were shown to include temperature (Imada \& Muroga 1977, 1978, Golovin \& Shukhgalter 1979, Chan \& Wu 1984) and pH (Golovin \& Shukhgalter 1979).

The objective of the present study was to determine the abundance and prevalence of Pseudodactylogyrus anguillae and $P$. bini in European eels Anguilla anguilla kept in a Danish eel farm for a period of $30 \mathrm{wk}$. We wanted to know if additional factors regulate the infection level in an intensive fish culture system, based on recirculated water, kept at constant temperature and $\mathrm{pH}$.

\section{MATERIALS AND METHODS}

Culture system. We used a quasi-closed warm freshwater system consisting of fish tanks arranged in parallel. The water was aerated and recirculated by biorotors. Data for the system are shown in Table 1.

Eels. Elvers of the European eel Anguilla anguulla were placed in the fish tanks 2 mo before starting the survey. Samples of 15 to 44 eels (total: 608 individuals) were examined weekly, immediately after capture in the same fish tank. Total body length was recorded (Fig. 2A).

Parasites. Postlarvae on eel gills were shown to be Pseudodactylogyrus sp., whereas adult parasites were determined as $P$. anguillae or $P$. bini. Abundance (No. of parasites per host, both infected and uninfected) and prevalence (percentage of eels infected) were used as defined by Margolis et al. (1982).

Biological parameters. Free-living fauna in sediment and water in the fish tank was determined weekly as absent, poor or abundant.

Physico-chemical parameters. Daily semi-quantitative tests were performed on fish-tank water for

Table 1. Quantitative data of the eel-culture system employed.

$\begin{array}{lc}\text { Total water volume } & 33 \mathrm{~m}^{3} \\ \text { No. of fish tanks }\left(3 \mathrm{~m}^{3}\right) & 9 \\ \text { Volume of bio-rotor tank } & 6 \mathrm{~m}^{3} \\ \text { Maximum depth of fish tanks } & 75 \mathrm{~cm} \\ \text { No. of bio-rotors } & 4 \\ \text { Surface area of rotors } & 570 \mathrm{~m}^{2} \\ \text { Surface area of submerged bio-filters } & 390 \mathrm{~m}^{2} \\ \text { Recirculation } & 36 \text { times per } 24 \mathrm{~h} \\ \text { Water-renewal d } & 4-5 \% \\ \text { Stocking density } & 8 \mathrm{~kg} \mathrm{~m}\end{array}$




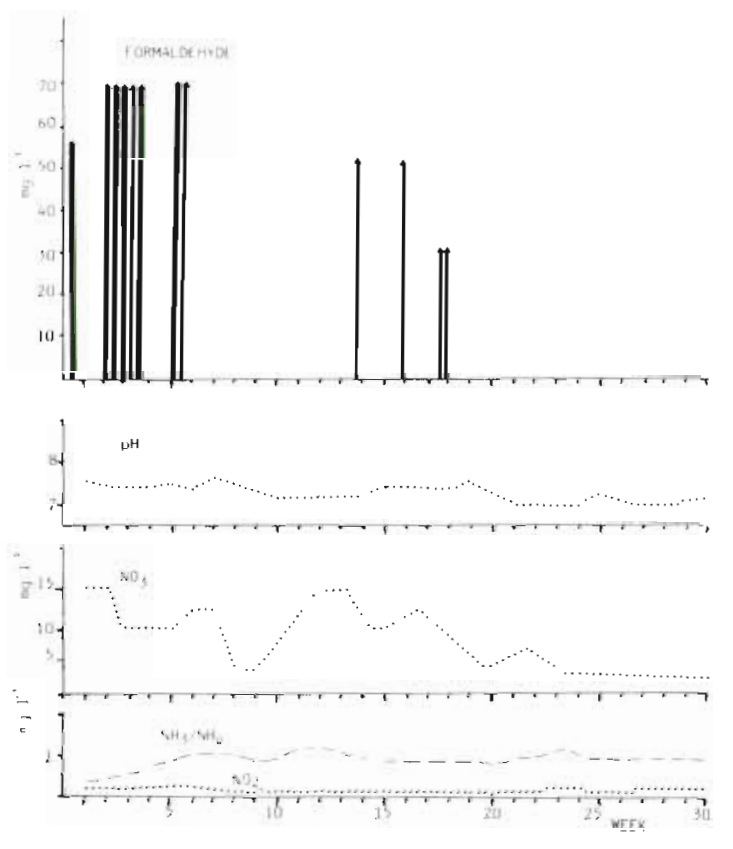

Fig. 1 Physico-chemical parameters of the fish-tank water during investigation. Column height indicates maximum-concentrations of formaldehyde reached immediately after formaldehyde-addition

ammonia (Hach No. 1854), nitrate (Hach No. 14038) and nitrite (Hach No. 20596) (Fig. 1). Secchi disc transparency was recorded weekly (Fig. 2C). Continuous monotoring was performed for oxygen (pHox systems Ltd, series 65), pH (Great Lakes Instrument, Inc, 570P) (Fig, 1), and temperature (Shimaden SR 17).

Eel feed. Eels were fed automatically on commercial granulated dry feed $(50 \%$ protein, $20 \%$ fat, $11 \%$ carbohydrate, $8 \%$ ash). The amounts of dry feed per $\mathrm{m}^{3}$ fish tank water given weekly are listed in Fig. 2B.

Management protocol. On 2 occasions (Fig. 3A) 3 tanks of the eel culture system were emptied of water and the bio-film and sediment on the inner walls of the subunits were removed. On several occasions (Fig. 3A), $37 \%$ formaldehyde was added to the fish tank water. Formaldehyde concentrations were monitored by test strips (Merckoquant 10036, Merck) (Fig. 1).

Cage-experiments. To examine possible spatial differences in infection pressure, 2 groups of eels ( 9 to $10 \mathrm{~cm}$ ) were treated with dexamethasone (see below) and placed in cages $(22.5 \times 23.5 \times 29.5 \mathrm{~cm})$ at the surface and bottom of the tank respectively during a period of heavy settling of oncomiracidia. After $5 \mathrm{~d}$ the 2 eel groups were examined for postlarvae and compared (Table 2).

To detect if formaldehyde-treatment impaired the eels' resistance to reinfection, one group of eels ( 9 to $10 \mathrm{~cm})$ was treated with formaldehyde $(50 \mathrm{ppm})$ in the
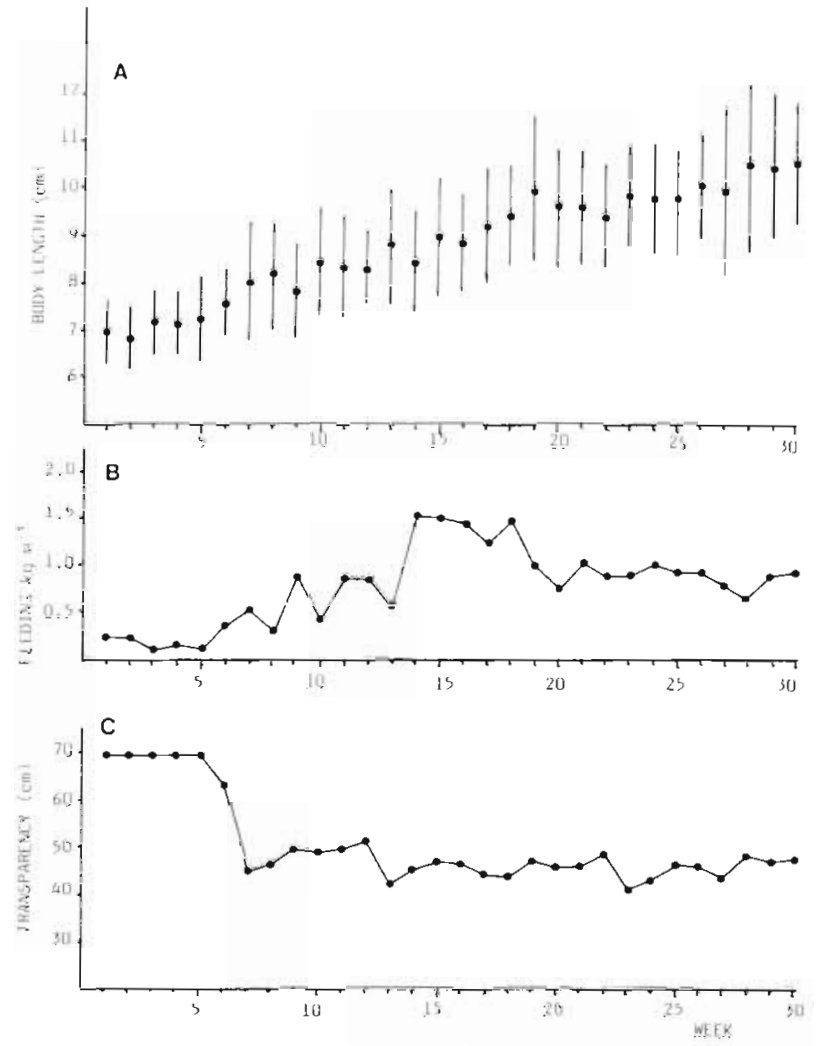

Fig. 2. (A) Arithmetic mean of eel body length (dots $\pm \mathrm{SD}$ [vertical bars]) of eels examined in weekly samples. (B) Amount of dry feed given per $\mathrm{m}^{3}$ fish tank water per week. (C) Secchi disc transparency of fish tank water

fish tank, whereas another group was kept untreated. The 2 groups of eels were then placed in cages at the water surface of the fish tank and thus exposed to oncomiracidia. After $5 \mathrm{~d}$ the degree of infection with postlarvae was determined (Table 2).

To test for cortico-steroid-labile resistance of eels to reinfection, eels $(9$ to $10 \mathrm{~cm}$ ) were injected intraperitoneally with dexamethasone $\left(40 \mu \mathrm{g} \mathrm{g}^{-1}\right.$ ) (Fluoromethyl-prednisolone vet. Ferrosan). According to Reynolds (1982) this concentration corresponds to concentrations of Triamcinolone acetonide, which inhibited the immune resistance in carp (Houghton \& Matthews 1986). This treatment also increased the susceptibility of eels to reinfection with Pseudodactylogyrus spp. (Buchmann unpubl.). Eels were placed in cages at the water surface in Weeks 13 and 14, when no larvae settled on untreated eels (Table 2).

Predation experiment. To test bio-film organisms for their ability to predate on Pseudodactylogyrus eggs, eggs were placed in tap water in Petri dishes together with isolated rotifers, copepods, ciliates or turbellarians. The organisms were studied for 2 h under a dissecting microscope (20 and $40 \times$ magnification). 

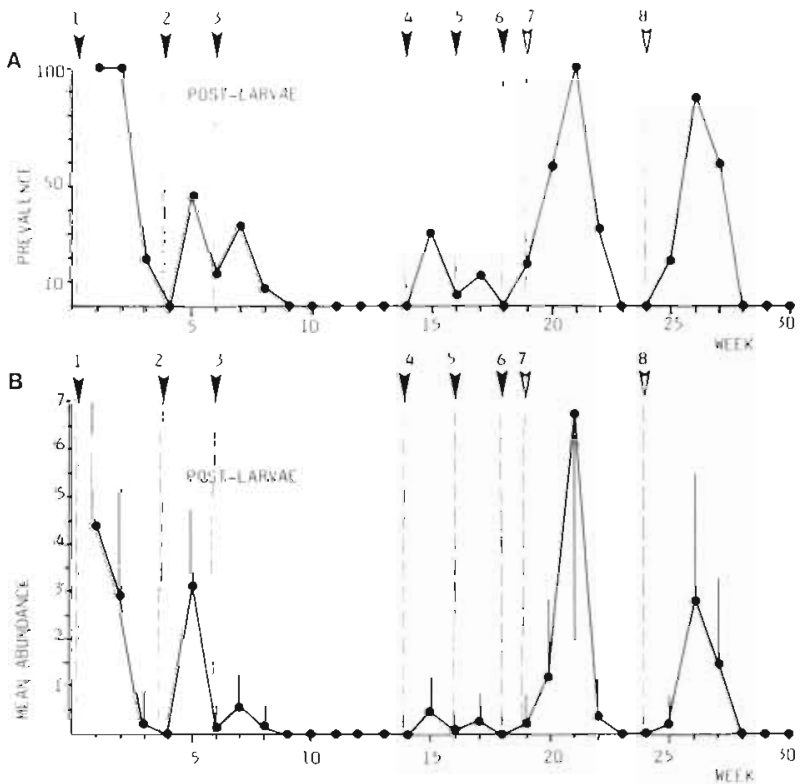
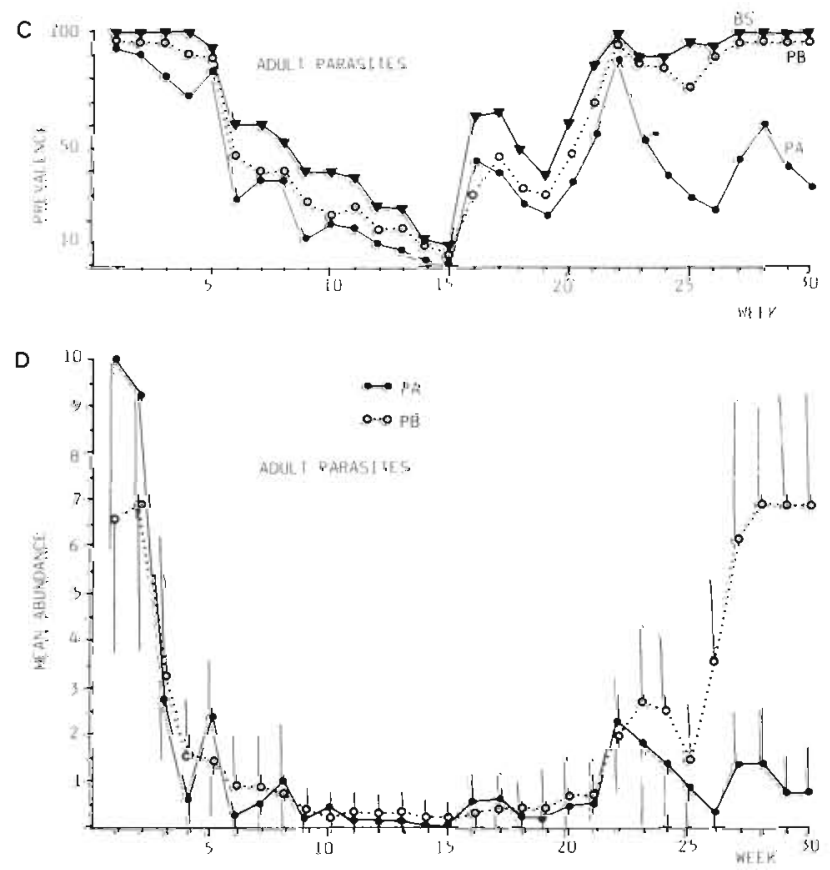

Fig. 3. (A) Prevalence (percentage of examined eels infected) of monogenean postlarvae. Numbers above arrow heads: 1-6, end of formaldehyde treatment indicated in Fig. 1; 7 \& 8, cleaning and removal of biofilm from 3 fish tanks. (B) Mean abundance of postlarvae. Vertical bars: standard deviation. (C) Prevalence of Pseudodactylogyrus bini (PB), P. anguillae (PA) and of both species combined (BS). (D) Mean abundance of both adult parasite species. Vertical bars: standard deviation. PB: Pseudodactylogyrus bini; PA: P. anguillae

Table 2. Cage experiments. Mean number of monogenean postlarvae on gills of European eels after $5 \mathrm{~d}$ of exposure (MannWhitney U-test)

\begin{tabular}{|lccc|}
\hline Treatment & Week No. & No. of eels & Mean abundance \pm SD \\
\hline $\begin{array}{l}\text { Dexamethasone } \\
\text { Dexamethasone }\end{array}$ & 13 & 19 & 0 \\
Eels at the water surface & 14 & 12 & 0 \\
(Dexamethasone-treated) & 15 & 12 & $5.8 \pm 3.6$ \\
Eels at the bottom & 15 & 12 & $3.0 \pm 2.3$ \\
(Dexamethasone-treated) & 17 & 10 & $1.8 \pm 1.6$ \\
Formaldehyde (50 ppm) & 17 & 10 & $2.5 \pm 2.5$ \\
No formaldehyde & & & - \\
\hline
\end{tabular}

\section{RESULTS}

\section{Physico-chemical parameters}

During the investigation the oxygen level was kept between 50 and $60 \%$ saturation, temperature was $25^{\circ} \mathrm{C} \pm 1.0$. Changes of these parameters - and, as appears from Fig. 1, changes of $\mathrm{pH}$, ammonia, nitrite and nitrate - were not correlated to changes in the infection level.

At the beginning of the survey the total water column was transparent. However, due to increased feeding from Week 6, transparency decreased markedly (Fig. $2 \mathrm{C}$ ); it varied only slightly during the following period.
Transparency decreased simultaneously to a decrease in larvae-settling from Week 7; however transparency increased insignificantly only during the following outbreaks of reinfection.

\section{Biological parameters}

During every formaldehyde-treatment the abundance of the free-living fauna (ciliates, rotifers, Cyclops sp., nematodes, turbellarians and oligochaetes) was severely reduced, both in fish-tank water and in the biofilm adhering to the fish-tank walls. This decrease lasted 1 wk. After biofilm adhering to the fish-tank 
walls was removed it was 2 wk before the walls were fully re-colonized by micro-organisms.

Eels. Body length of eels increased from 6.9 to 10.5 $\mathrm{cm}$ (mean values) during the survey This corresponds to a weight increase from 0.4 to $2.0 \mathrm{~g}$ per individual.

\section{Prevalence and abundance}

At the beginning of the survey, the infection level was rather high (Fig. 3). Formaldehyde had been added 1 wk before starting the survey. Intensive formaldehyde treatment was implemented in Week 2 (Fig. 1). This prevented reinfection and the adult parasite population decreased (Fig. 3D). However, 1 wk after the treatment was discontinued, a surge of larva-settling occurrod (Week 5) (Fig. 3A, B). A new treatment in Week 6 was also followed by a reinfection. Feeding was elevated from Week 6 (Fig. 2B), and the infection level declined. During the next 7 wk no postlarvae were observed (Fig. 3A, B). In this period a steady decline of prevalence and abundance of adult parasites was recorded (Fig. 3C, D). In Week 15 the infection level was very low, but a formaldehyde treatment was performed to reduce the concentration of ciliates in the water. In the following week postlarvae were observed on the eels for the first time in $7 \mathrm{wk}$ (Fig. $3 \mathrm{~A}, \mathrm{~B})$. Formaldehyde treatment in Weeks 16 and 18 also produced an outbreak of larvae-settling in the following week (Fig. 3A, B)

In Weeks 19 and 24 (after sampling) 3 fish tanks were cleaned as described above. Cleaning procedures were followed by a severe outbreak of larvae-settling a week later (Fig. 3A, B).

\section{Cage-experiments}

No significant difference in larvae settling was recorded between formaldehyde-treated and untreated eels (Table 2). Dexamethasone-treated eels were not infected by postlarvae in Weeks 13 and 14 (Table 2). The infection pressure seemed to be higher at the water surface than at the bottom of the fish tank (Table 2).

\section{Predation experiment}

The only biofilm organism which was observed to ingest Pseudodactylogyrus eggs was Stenostomum sp. (Turbellaria). On 3 occasions it was seen to seize the eggs with the pharynx and to swallow them whole.

\section{DISCUSSION}

Larvae-settling of Pseudodactylogyrus spp. always occurred 1 wk after formaldehyde treatment or after removal of biofilm from fish-tank walls. It is acknowledged that fish in some cases are resistant to infections with monogencan gill parasites (e.g. Papcrna 1964, Mikryakov \& Stephanova 1983). Chemical treatment has been shown in some instances to increase susceptibility to such infections (Zharikova \& Flerov 1981). However, in this study formaldehyde-treated eels did not experience higher settling of larvae than untreated eels. The immunosuppressive drug dexamethasone did not elicit larvae settling on eels when no settling occurred on other eels in the fish tank. Therefore, variations in infection levels could not be explained by variations in the immune response of eels. Neither oviposition rate nor egg hatching seem to be influenced by formaldehyde (preliminary own laboratory observations). The low transparency of the fish tank water cannot explain the absence of reinfection, as the transparency was very low in Weeks 20 and 25, when heavy reinfections occurred.

While other factors (e.g. killing of parasite eggs in anaerobic zones in the sediment) may be involved, the predation experiment suggests the predatory activities of Stenostomum sp. in the biofilm to affect the degree of infection pressure in the fish tanks. Between 22 and $30^{\circ} \mathrm{C}$, eggs of Pseudodactylogyrus spp. hatch after 2 to $6 d$, and the life span of the oncomiracidia is less than $1 \mathrm{~d}$ (Buchmann et al. 1987).

Thus it is seen that when parasite eggs are allowed to develop and hatch, postlarvae will be found on the eel gills about 1 wk after oviposition. This happens when the egg-eating turbellarians are killed by formaldehyde or are removed from the fish tank walls due to cleaning Future research must elucidate whether predatory activities of these organisms affect egg survival to such a degree that it can account for the observed variations in infection level. Additional parameters not recorded in this study could also be of importance. Bulaev (1982) demonstrated that Cyclops vicinus eliminated cercariae (species of Diplostomum and Echinostoma) by predation. The potential impact of predatory copepods on populations of oncomiracidia should be further investigated. Also, a possible inhibition of parasite eggs in anaerobic zones in the sediment should be elucidated

Acknowledgements. This work was supported by a grant from the Danish Agricultural and Veterinary Research Council. The author is indebted to the staff at Knarregaard Eel Farm. Denmark, for skillful management operations. Encouraging discussions with Drs J. L. Larsen and J. Monrad are acknowledged.

\section{LITERATURE CITED}

Buchmann, K., Meliergaard, S., Koie, M. (1987). Pseudodactylogyrus infections in eel: a review. Dis. aquat. Org. 3 $51-57$

Bulaev, A. I. (1982). Experimental study of the elimination of 
cercariae by freshwater crustaceans Cyclops vicinus (order Cyclopoida). In: Gel'minty v presnovodnykh biotsenozakh Moscow, USSR. Nauka 1982: 73-81

Chan, B., Wu, B. (1984). Studies on the pathogenicity, biology and treatment of Pseudodactylogyrus for the eels in fishfarms. Acta zool sin. 30: 173-180

Chung, H.-Y., Lin, I.-H., Kou, G.-H. (1984). Study of the parasites on the gills of cultured eel in Taiwan. Council of Agriculture, Taiwan. Fisheries Series, No. 10, Fish Dis. Res. (VI): 24-33

Egusa, S. (1979). Notes on the culture of the European eel (Anguilla anguilla, L.) in Japanecse eel farming ponds. Rapp. P.-v. Réun. Cons. int. Explor. Mer 174: 51-58

Golovin, P. P., Shukhgalter, O. A. (1979). The biology of the monogenean parasites of eels from the genus Pseudodactylogyrus. Sb. nauch Trud. vses, nachno-issled Inst. prud. ryb. Khozyaistva (Bolezni ryb i bor'ba s nimi) 23: 107-116

Houghton, G., Matthews, R. A. (1986). Immunosuppression of carp (Cyprinus carpio L.) to ichthyophthiriasis using the corticosteroid Triamcinolone acetonide. Vet. Immunol. Immunopathol. 12: 413-419

Imada, R., Muroga, K. (1977). Pseudodactylogyrus microrchis (Monogenea) on the gills of cultured eels - I. Seasonal changes in abundance. Bull. Jap. Soc. scient. Fish. 43: $1397-1401$

Imada, R., Muroga, K. (1978). Pseudodactylogyrus microrchis
(Monogenea) on the gills of cultured eels - II. Oviposition, hatching and development on the host. Bull. Jap. Soc. scient. Fish. 44: 571-576

Margolis, L., Esch, G. W., Holmes, J. C., Kuris, A M., Schad, G. A. (1982). The use of ecological terms in parasitology (report of an ad hoc commitee of the American Society of Parasitologists). J. Parasitol. 68: 131-133

Mikryakov, V P., Stephanova, M. A. (1983). Infection of Abramis ballerus with Dactylogyrus chranilowi (Monogenoidea, Dactylogyridea Bikhovski, 1937) correlated to the antimicrobial activity of host serum. Biologiya Vnutrennikh Vod, Informatsionnyi Byulleten '57: 34-36

Ogawa, K., Egusa, S. (1976). Studies on eel pseudodactylogyrosis - I. Morphology and classification of three eel dactylogyrids with a proposal of a new species Pseudodactylogyrus microrchis. Bull. Jap. Soc. scient. Fish. 51: 381-385

Paperna, I. (1964). Competitive exclusion of Dactylogyrus extensus by Dactylogyrus vastator (Trematoda, Monogenea) on the gills of reared carp. J. parasitol. 50: 94-98

Reynolds, J. E. F. (1982). Martindale the extra Pharmacopoea. The Pharmaceutical Press, London

Zharikova, T I., Flerov, B. A. (1981). The effect of chlorophos on the susceptibility of fish to infection with species of Dactylogyrus Diesing, 1850 (Monogenoidea). Biologiya Vnutrennykh Vod, Informatsionyi Byulleten 49: 43-46 